\author{
Journal of Markeing and Information Systems \\ (JMIS) \\ ISSN: \\ www.readersinsight.net/jmis
}

\title{
Green Marketing and Competitive Advantage of Table Water Production in Nigeria
}

\author{
Ebhote Oseremen \\ Department of Business Administration Samuel Adegboyega University, Ogwa, Edo State.
}

* Corresponding author: oseremenebhote@gmail.com

\begin{abstract}
The study examined the relationship between green marketing and competitive advantage of table water production in Nigeria. The objective of the paper is to investigate green marketing and competitive advantage in the production of table water in Nigeria. 227 table water companies/factory formed the sample of the study drawn randomly across Edo State, Nigeria. The study used Ordinary Least Squares (OLS) multiple regression method to analyse the data collected from respondents. The study's findings reveal that eco-labelling had no significant relationship with competitive advantage while environmental advertising was found to be significant and positively related to competitive advantage in the table water industry in Nigeria. The study recommended that table water companies/factories should obtain eco-certification of their table water from certification agencies as well as embarking on green advertisement devoid of greenwash.
\end{abstract}

Keywords: Advertisement, Eco-labelling, Green, Certification, Competitive

ARTICLE INFORMATION

Received: 07 January 2019 Revised: 23 January 2019 Accepted: 15 February 2019

DOI: $10.31580 / j m i s . v 112.864$

\section{INTRODUCTION}

Today, ecological issue has become a global challenge due to universal ecological degradation, pressure from global community, the exertions of governments, the eco-friendly movement and the influence of public media. Therefore, promoting eco-friendliness is assumed to be a service to humanity to sustain human development. Environmental safety is seen as the art of safeguarding the physical environment of the individual, organisation or government for the utmost advantage of both the ecological environment and humans. This has motivated the development of green marketing which promotes an increasing market for green and mutually responsible products. Srinivasa (2014) posits that the adventure into green marketing or environmental marketing is a definite indicator that the nation is gradually moving to achieve a greener and greater Nigeria where environmental consideration is included into all facets of marketing such as product improvement and advertisement. Karatu and Mat (2015) asserts that in spite of international responsiveness as touching the natural environment and green marketing, research discovered that only $5 \%$ of the Nigerian populations are involved in green buying behaviour. They also reported that the Nigerian society are equally faced with problems such as inadequate green knowledge about products, low level of environmental consciousness, inadequate government control, increased prices of green products as well as distrust for products that are termed green.

Green marketing has gained popularity over other marketing approaches due to the exceptional role it plays in society (Ajike, Amos \& Kabuoh, 2015). The practice of green marketing will immensely aid manufacturing firms especially table water companies to obtain competitive advantage in the sense that environmentally friendly firms possess good and better corporate image and reputation in society. This image and reputation imply the firms' perception in the eyes of the general public could lead to customer loyalty and in turn increase the firm's market share and consequently, its profitability. Table water production in Nigeria is receiving new entrant on daily basis due to the lucrativeness of the business and the need to provide Nigerians with clean and affordable water as well as provision of employment opportunities to the teeming population. Research in this sector is timely as effort are been made by government to encourage the non-oil sector. Therefore, research in the area of table water production will be of great significance.

\section{Problem Statement}

Water is life as man need water to survive. Basically, this is why the business of table water production is booming on a daily basis in Nigeria. Infact, statistics reveal that National Agency for Food Drug Administration and Control (NAFDAC) register 3000 new table water factory/companies very year. Sadly however, over 2000 of table water companies closed down business in Nigeria within the first two years of commencement (dayoadetiloye.com). The failure of these companies few years after establishment could be linked to their inability to practice green marketing which is aimed at providing consumers with eco-friendly products that are safe for consumption. Founders of these failed table water companies after spending fortune on heavy equipment and other facilities neglect the aspect that is very important to consumers which is producing safe and hygienic water that could stand the taste of time. Also, they are oblivion of the fact that when they go green they can be able to compete with other companies better thereby reaping competitive advantage that is sustainable. This is the essence of this study green marketing and sustainable competitive advantage of table water production in Nigeria.

\section{Research Questions}

In the light of the above identified problem, the research questions were: 
1. What is the relationship between eco-labelling and competitive advantage of table water production in Nigeria?

2. What is the relationship between environmental advertisement and competitive advantage of table water production in Nigeria.

\section{Objectives of the Study}

The broad objective of this study was to examine green marketing practices and competitive advantage of table water production in Nigeria. Based on the research work of Narges, Mohammad \& Bahareh, 2014; The specific objectives were to:

1. examine the relationship between eco-labelling and competitive advantage of table water production in Nigeria.

2. determine the relationship between environmental advertisement and competitive advantage of table water production in Nigeria.

\section{Research Hypotheses}

The study formulated the following null hypothesis.

i. Ho: Eco-labelling has no effect on competitive advantage of table water production in Nigeria.

ii. Ho: Environmental advertisement has no effect on competitive advantage of table water production in Nigeria.

\section{Scope of the Study}

This study focused on green marketing and competitive advantage of table water production in Nigeria. The thrust of the study is based on variables such as eco-labeling, environmental advertisement and competitive advantage in terms of concept, theories and related empirical studies both in Nigeria and abroad. The study covered perceived view of factory managers of (227) registered table water companies which were randomly drawn from table water factories operating in Edo State, Nigeria. The choice of Edo is due to the presence of substantial table water factory which could serve as a basis for drawing inference.

\section{LITERATURE REVIEW}

\section{Concept of Green Marketing}

Green marketing is an evolving marketing strategy that includes numerous tasks like fair-trade practices, changes in products, production and packaging that is eco-friendly (Mishra \& Sharma, 2012). Marketers have understood the need for and worth of green marketing due to pubic concerns over the ecological decline in the past years (Kinoti, 2011). Organisations just did not need regulatory conformity to practise green marketing because it includes theoretical tools like pollution prevention, product stewardship and corporate responsibility which is significant to them (Chang \& Fong, 2010). Green marketing is a management process responsible for spotting, anticipating and meeting the obligations of consumers and society in a lucrative and sustainable way. Green marketing can also be looked at as satisfying customer's needs and accomplishing the goals of the organisation, its processes is rational with the environment in the development of products, pricing, promotion and distributing as well as planning, implementing and controlling of marketing activities (Kumar, Rahman, Kazmi \& Goyal, 2013). Thulasimani (2012) posits that green marketing is manufacturing products aimed at covering the entire process of assessment about the environment and the structure of activities with ecofriendly protection awareness rather than making a profit.

Mukesh, Komal and Rajendra (2016) opines that as the society becomes concerned with protecting the natural environment, businesses reform their strategies and practices in order to influence environmental issues in society. With this increase in consciousness, most especially in developed countries, consumers too are becoming conscious of environmental concerns like global warming, grogginess of the natural resources and extreme changes in climatic conditions. Iweama (2008) posits that $30 \%$ of Nigerian organisations are ecofriendly though consumers are not sufficiently knowledgeable on green marketing principles. Nkamnebe (2009) reports that environmental marketing is a business practice that considered consumer issues about promoting, maintaining and safeguarding the natural environment.

\section{ECO-LABELING}

Eco-branding is a market tool which helps both firms and consumers to achieve justifiable goals and contribute to environmental protection and amelioration (Shahriar \& Mahbubul, 2016). Eco-branding is regarded as a market tool that facilitates both companies and consumers achieving sustainable objectives and adding value to environmental protection and amelioration. Ecobranding confirms that a product meets stated environmental performance standards. Generally speaking, the manufacturers and service providers communicate their greenness through a particular proclamations or symbols. Besides, some third-party organizations award a product or service 'eco-label' that is determined to satisfy precise environmental standard (Singh, 2013).

The International Organization for Standardization IOS (1999) classified the current environmental labels into three: Type I, II \& III; Type-I labels are "deliberate and "multi-criterion -based" branding that recognizes positive environmental characteristics of the product (Low, 2014). Type-II labels are developed by firms with a view to describing the environmental benefits of their products and or services in the form of declarations, logos, commercials, etc. (Low, 2014) and Type-III labels comprise of quantified information about the product life-cycle effects that are certified by a competent third party. Ecobranding occurred due to the pressure on firms emanating from governments (regulatory body), consumers, shareholders, employees and partners to embrace more sustainable and green practices (Singh 2013).

\section{ENVIRONMENTAL ADVERTISING}

In the advent of prompt consumer concern about the environment, in the late 1980s and early 1990s, green marketing activities evolved, especially in the field of environmental advertising. Environmental advertisement is implemented by firms to enhanced green movements globally and to increase public consciousness of environmental challenges. Most organisations prefer environmental advertisements through media or newspapers as green in today's society. Environmental advertisement is seen as a strategy to introduce a firm's products to customers who are environmentally responsive. Green advertisement is a way to stimulate consumers' buying attitude and behaviour. Environmental advertisement strongly persuades consumers to patronize products that are environmentally friendly in the market besides the benefit of concentrating their focus to the positive consequences of their buying behaviour not only for themselves but for the environment in general (Delafrooz, Taleghani \& Nouri, 2014).

Davis (1994) posits that there are three factors in green advertisement. The first is a condition where the firm advertisement communicates a statement that is connected to the environment. Secondly, the firm will demonstrate its concern and commitment to improve the environment by its changed modus operandi from the green advertisement. Finally, the green advert discloses a precise environmental accomplishment where the firm will be encouraged by green advertisement (Rahbar \& Wahid, 2011). It is believed that a number of firms supporting environmental interest in the course of their advertisement has increased, even though some of these firms merely green wash. It is a saying that when a firm involves in environmental advertisement free from green washing, such a firm can enjoy the benefit of gaining competitive advantage over firms that do not engage environmental advertisement.

\section{COMPETITIVE ADVANTAGE}

Competitive advantage is seen as any innovation, product, service, patent or anything else that differentiates the firm in a 
positive way from other firms (Rijamampianana, Abratt \& February, 2003). Porter (1995) noted that competitive advantage originates from a firm's ability to accomplish the required responsibilities at a collectively lower cost than competitors or perform some tasks in a exceptional way that creates buyer value and hence permits the firm to command a premium price. A significant feature of competitive advantage is the way activities fit and strengthen one another. Since strategy involves the entire system of activities done by a firm, and not a collection of parts, one activity cost is lessened because of the way other activities are completed. Similarly, one activity's value to customers can be improved by a firm's other activities (Porter, 1995).

\section{Benefits of Green Marketing Practices}

EMD Project (2009) cited in Nkamnebe (2011) show that the most significant opportunities for actively pursuing more sustainable approaches (green marketing) to business include:

i. Save costs and increase productivity by reducing environmental impacts and treating employees well.

ii. Access new customers and markets through environmental improvements and benefits to the local economy.

iii. Reduce risk through engagement with stakeholders.

iv. Build reputation by increasing environmental efficiency.

v. Develop human capital through better human resource management; and

vi. Improve access to capital through better governance.

\section{THEORETICAL FRAMEWORK}

The theory of planned behaviour is a model extensively applied when examining pro-environmental behaviour as well as recycling, travel mode choice, energy depletion, water preservation, food choice and ethical venture (Stern, 2000). The theory of Planned Behavior (TPB) foretells an individual's intent to exhibit a behaviour at a particular time and place. The theory assumes that an individual's behaviour is determined by behaviour intentions (Ajzen, 1991). According to Azjen, three factors elucidate behavioural intention, i.e, the attitude (beliefs of individual regarding the behaviour), the subjective norm (beliefs of others regarding the behaviour) and the observed behavioral control (self-efficacy regarding the behaviour). The theory of Planned Behaviour predicts that consumers takes decisions by analyzing the costs and paybacks of the diverse sequences of action and selecting the choice that exploits their anticipated net benefits. The model could also be considered as 'rational choice models'. The application of the theory of planned behaviour is relevant to this study in the sense that it postulates that consumers take rational decisions by analyzing the implication and anticipated returns of various courses of action and deciding on the one that best satisfy them. In actual fact, consumer awareness towards environmentally friendly products is on the increase, they now prefer products that will not constitutes hazards to their wellbeing even though the cost of such products may be a bit higher, this dovetail with the rational decision making of the consumers as advocated by the theory of planned behaviour with regard to considering the cost and benefits of their decision.

\section{RESEARCH METHODOLOGY}

The survey research method was adopted to generate relevant data for the study. The use of survey research method is justified since the study involves ascertaining views, beliefs, opinions and attitudes of respondents. The population of this study covers all National Agency for Food Drug Administration and Control registered table water factories in Edo State, Nigeria. The choice of Edo state is due to the presence of sizeable number of table water factories in the state. To select the required samples, the study used random sampling technique to drew our samples from the five hundred and twentyseven (527) registered table water factories operating in Edo State. (National Agency for Food Drug Administration and Control, 2019).
Therefore, a sample size of 227 table water factories was randomly selected using lottery method for this study. This was arrived with the aid of Taro Yamane (Yamane, 1967) formula with $95 \%$ confidence level. The formula of Taro Yamane is showed as follows:

$\frac{\mathrm{N}}{1+\mathrm{N}(\mathrm{e})^{2}}$
Where:
$\mathrm{n}$ - Sample size
$\mathrm{N}$ - Total number of registered table water in Edo/Delta
$\mathrm{e}-$ Error term
$=\frac{527}{1+527(0.05)^{2}}$
$=\frac{527}{1+1.3175}$
$\mathrm{n}=\frac{527}{2.3175}$
$=$

The study got germane information from the insight of the factory managers or their designate. It was believed that the factory manager being the head or the manager can furnish the researcher with the needed information based on their knowledge about the factory. The data obtained from the study were analysed using sequential analysis involving descriptive statistics and Ordinary Least Squares (OLS) multiple regression technique. The use of regression analysis was justified because the influence of each of the explanatory variables (sustainable marketing variables) on the dependent variable (competitive advantage) was best captured by regression analysis. Pursuant to this, the relevant hypotheses were thus tested. The Statistical Packages for Social Sciences (SPSS version 22) were utilized for the econometric estimation.

\section{DATA ANALYSIS}

The data gathered from the respondents through the sets of questionnaires administered were analysed using tables and simple percentage. Out of the 227 questionnaires distributed, 220 was returned filled representing $97 \%$ response rate and this was used as the unit of analysis.

Table 1 - Eco-labelling of Firms

\begin{tabular}{|c|c|c|c|c|c|c|}
\hline Variables & ๘ & $\varangle$ & ב & 0 & ம & $\stackrel{\overline{\mathbb{J}}}{\Sigma}$ \\
\hline Factors & 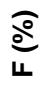 & 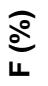 & 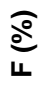 & 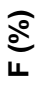 & $\frac{\overparen{0}}{4}$ & \\
\hline $\begin{array}{l}\text { In your opinion, is eco-labelling significant in } \\
\text { marketing? }\end{array}$ & $\begin{array}{l}\text { ナे } \\
\stackrel{\oplus}{\infty} \\
\stackrel{\infty}{\circ}\end{array}$ & 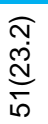 & 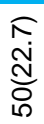 & 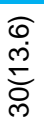 & $\widehat{\stackrel{+}{\sigma}}$ & $\frac{\infty}{n}$ \\
\hline $\begin{array}{l}\text { Does your organisation pay attention to eco- } \\
\text { labelling? }\end{array}$ & 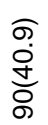 & 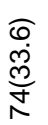 & $\frac{\sigma}{\infty}$ & E़ & 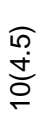 & $\begin{array}{l}\stackrel{n}{N} \\
\dot{m}\end{array}$ \\
\hline $\begin{array}{l}\text { Knowledge of green labels on products' } \\
\text { packaging and instructions is important for } \\
\text { organisations. }\end{array}$ & 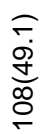 & 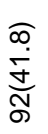 & $\frac{\overparen{f}}{\stackrel{\Gamma}{\check{c}}}$ & 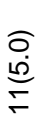 & $\frac{\widehat{N}}{\stackrel{N}{0}}$ & $\begin{array}{l}5 \\
\end{array}$ \\
\hline $\begin{array}{l}\text { Our company understands the certification } \\
\text { authority of the green labels/ its meaning. }\end{array}$ & $\begin{array}{l}\text { क़ } \\
\text { மூ } \\
\text { क़ }\end{array}$ & 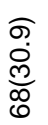 & 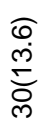 & $\begin{array}{c}\text { T̃ } \\
\stackrel{N}{\infty} \\
\stackrel{N}{N}\end{array}$ & $\begin{array}{l}\widehat{\sigma} \\
\stackrel{\omega}{0} \\
\stackrel{0}{n}\end{array}$ & $\underset{+}{+}$ \\
\hline $\begin{array}{l}\text { My company believes that the green labels } \\
\text { on the products make it reliable and } \\
\text { adherence to green standard. }\end{array}$ & 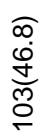 & 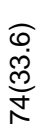 & $\begin{array}{l}\underset{f}{\sigma} \\
\stackrel{\sigma}{t}\end{array}$ & Ðே & $\underset{\check{r}}{\stackrel{+}{\sigma}}$ & \begin{tabular}{l}
5 \\
\hdashline
\end{tabular} \\
\hline
\end{tabular}




\section{Variables}

के $\varangle \supset$ ○ के

Factors
$\begin{aligned} & \text { Information about the green labels on the } \\ & \text { packaging of our products is accurate. }\end{aligned}$
My company believes that products with
green labels are more attractive to buyers

green labels are more attractive to buyers.

My company believes that the probability of acceptance of products with green labels is high.

ஓ

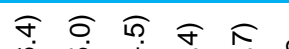

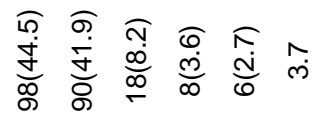

Source: Author's field work, 2019

Table 4.2.4 showed respondents' opinions on the significance of eco-labelling in marketing. Narges, Mohammad, and Bahareh (2014) identified factors eco-labelling as a factor of green marketing practices. It was in the light of this that the researcher wanted to know if eco-labelling was important. The respondents opined as follows: strongly agree 80 respondents representing $36.4 \%$ of the total respondents, 51 respondents representing $23.2 \%$ agreed that ecolabelling was significance in marketing, 50 respondents representing $22.7 \%$ of the total respondents were undecided, $30 \%$ disagreed on the significant of eco-labelling in marketing while $4.1 \%$ strongly disagreed. Therefore, most respondents opined that eco-labelling was important in marketing. The second research question attempted to know whether their firms' paid attention to the concept in their manufacturing activities. They responded as follow: strongly agree $40.9 \%$, agree $33.6 \%$, undecided $15.9 \%$, disagreed $9.1 \%$ and strongly disagree $4.5 \%$.

The third research question attempt to get information on whether knowledge of green labels on products' packaging and instructions was important for firms and consumers as well. Again, the respondents opined as follow: 108 respondents representing $49.1 \%$ of the total respondents strongly agreed with the assertion, 92 respondents agreed, 03 respondents were undecided, 11 respondents amounting to 5\% disagreed while 06 respondents amounting to $2.7 \%$ strongly disagreed with the assertion. The fourth statement on the table revealed the understanding the firm regarding certification authority of green labels. On this statement 79 respondents opined that they have full understanding of certification authority on green label, 68 respondents agreed with the assertion, 30 respondents were undecided, 28 respondents disagreed while 15 respondents strongly agreed. My company believe that the green labels on products makes it reliable and adherence to green standard and this was the focus of research question five. The responses obtained are as follow: 103 respondents amounting to $46.8 \%$ of the total entire sample strongly agreed, 77 respondents amounting to $35.0 \%$ of the entire sample agreed with the assertion, 32 respondents amounting to $14.5 \%$ were undecided, 14 respondents amounting to $6.4 \%$ of entire sample disagreed while $4.1 \%$ strongly disagreed.

Information about the green labels on the packaging of our products is accurate and this was the focus of research question six. The responses obtained from respondents were as follow: 80 respondents representing $36.4 \%$ of the respondents strongly agreed, agreed $35 \%, 32$ respondents representing $14.5 \%$ of the respondents were undecided, 14 respondents amounting to $6.4 \%$ of the entire sample disagreed while 17 respondents amounting to $7.7 \%$ of the entire respondents strongly disagreed with the assertion. Products with green labels are more attractive to buyers and this was the focus of the seventh research question. The responses elicited from firms include: 94 respondents amounting to $42.7 \%$ of the entire sample strongly agreed, 70 respondents amounting to $31.8 \%$ of the entire sample agreed, $13.1 \%$ of the respondents were undecided, 15 respondents amounting to $6.8 \%$ of the entire sample disagreed while 12 respondents amounting to $5.6 \%$ of the entire sample strongly disagreed with the research question. Finally, my company believe that the probability of acceptance of products with green labels is high and this was the focus of the last research question on the table above. The respondent's opinion are as follows: 98 respondents representing $44.5 \%$ of the entire sample strongly agreed with the assertion, 90 respondents amounting to $41.9 \%$ of the total sample agreed, 18 respondents amounting to $8.2 \%$ of the entire respondents were undecided, 8 respondents amounting $3.6 \%$ of the entire respondents disagreed while 6 respondents amounting to entire $2.7 \%$ of the respondents however strongly disagreed with the statement. The aggregate mean value of firms CSR was 3.9, it meant that firms carried out corporate social responsibility activities.

Table 2 - Environmental Advertisement of Firms

\begin{tabular}{|c|c|c|c|c|c|c|}
\hline Variables & હ & $\varangle$ & כ & 0 & 仓े & $\sum_{\Sigma}^{\frac{\Phi}{\varpi}}$ \\
\hline Factors & $\stackrel{\widehat{\varrho}}{\longleftarrow}$ & $\frac{\Im}{\longleftarrow}$ & $\frac{\widehat{\varrho}}{4}$ & $\frac{\widehat{\varrho}}{\text { ๘ }}$ & $\underset{\leftarrow}{\stackrel{0}{\varrho}}$ & \\
\hline $\begin{array}{l}\text { My company's green advertising is } \\
\text { valuable to society. }\end{array}$ & $\begin{array}{l}\widehat{\infty} \\
\frac{m}{0} \\
\frac{0}{\alpha}\end{array}$ & 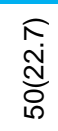 & 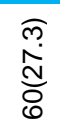 & $\begin{array}{l}\stackrel{N}{\infty} \\
\stackrel{\infty}{O}\end{array}$ & $\widehat{\varrho}$ & $\begin{array}{l}\infty \\
\infty \\
\dot{m}\end{array}$ \\
\hline $\begin{array}{l}\text { Advertising exploits environmental issues } \\
\text { instead of addressing them. }\end{array}$ & 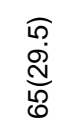 & 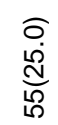 & 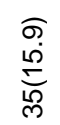 & 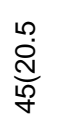 & 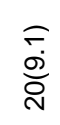 & $\underset{\dot{n}}{\bar{N}}$ \\
\hline $\begin{array}{l}\text { My company uses green advertising to } \\
\text { protect her reputation. }\end{array}$ & $\begin{array}{l}\text { గ } \\
\dot{0} \\
\stackrel{0}{\circ}\end{array}$ & $\frac{\widehat{L}}{\stackrel{1}{N}}$ & $\begin{array}{l}\text { ত̣ } \\
\infty \\
\stackrel{0}{\sigma}\end{array}$ & $\underset{\stackrel{+}{*}}{\stackrel{+}{\sim}}$ & 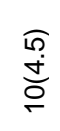 & $\underset{\dot{r}}{\bar{\gamma}}$ \\
\hline $\begin{array}{l}\text { Green advertising results in better } \\
\text { products for my company. }\end{array}$ & 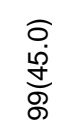 & 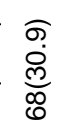 & $\begin{array}{l}\widehat{0} \\
\stackrel{m}{\circ} \\
\text { ס }\end{array}$ & $\frac{\bar{D}}{\stackrel{N}{N}}$ & $\underset{\text { ¿ }}{\stackrel{\forall}{*}}$ & 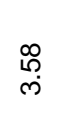 \\
\hline $\begin{array}{l}\text { Green advertising is a good source of } \\
\text { information about my company's product. }\end{array}$ & 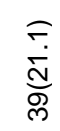 & $\begin{array}{l}\text { 官 } \\
\frac{\text { N }}{\text { N }}\end{array}$ & $\begin{array}{l}\text { N } \\
\stackrel{N}{N} \\
\text { N }\end{array}$ & $\stackrel{\mathbb{E}}{\stackrel{m}{\sigma}}$ & $\frac{\widehat{\sigma}}{\dot{\sigma}}$ & $\underset{+}{F}$ \\
\hline $\begin{array}{l}\text { My company's green advertising is good } \\
\text { at addressing environmental problems. }\end{array}$ & $\begin{array}{l}\widehat{\sigma} \\
\dot{0} \\
\stackrel{0}{0} \\
\stackrel{\infty}{0}\end{array}$ & 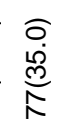 & 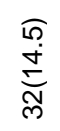 & 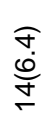 & $\frac{\mathbb{N}}{N}$ & $\begin{array}{l}\stackrel{\leftarrow}{\sim} \\
\dot{m}\end{array}$ \\
\hline $\begin{array}{l}\text { My company's green advertising is } \\
\text { trustworthy. }\end{array}$ & $\begin{array}{l}\text { ọ } \\
\text { ợ } \\
\text { ᄋ̆ }\end{array}$ & $\begin{array}{l}\widehat{6} \\
\stackrel{m}{m} \\
\frac{N}{N}\end{array}$ & 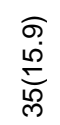 & $\frac{\bar{D}}{\stackrel{D}{N}}$ & $\begin{array}{l}\overparen{10} \\
\stackrel{0}{c}\end{array}$ & $\underset{\dot{\sigma}}{\sigma}$ \\
\hline $\begin{array}{l}\text { Green advertising strengthens my } \\
\text { company's image. }\end{array}$ & 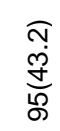 & $\frac{\infty}{\frac{\infty}{\infty}}$ & 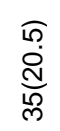 & 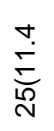 & 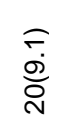 & $\underset{\dot{n}}{\bar{\kappa}}$ \\
\hline $\begin{array}{l}\text { Green advertising shows the consumer } \\
\text { that our firm addresses consumers' } \\
\text { environmental concerns. }\end{array}$ & $\begin{array}{l}\widehat{\sigma} \\
\infty \\
\stackrel{\infty}{\infty} \\
\stackrel{\infty}{\infty}\end{array}$ & $\begin{array}{l}10 \\
0 \\
0 \\
0 \\
0\end{array}$ & 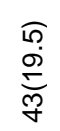 & $\stackrel{\substack{0 \\
\stackrel{0}{N}}}{\stackrel{0}{N}}$ & $\begin{array}{l}\widehat{\sigma} \\
\stackrel{\oplus}{N}\end{array}$ & $\underset{\Gamma}{\bar{m}}$ \\
\hline
\end{tabular}

Source: Author's field work, 2019

Table .2 showed the summary statistics on environmental advertisement. The essence was to get information on companies regarding their green advertisement. The first question was to solicit respondents' information on how valuable their green advertisement to the general public and they responded as thus: 70 respondents amounting to $31.8 \%$ of the entire respondents strongly agreed that their green advertisement was valuable to the society, 50 respondents representing $22.7 \%$ of the total respondents agreed with the above research question, 60 respondents amounting $27.3 \%$ of the respondents were undecided, 40 respondents amounting $18.2 \%$ of the entire respondents disagreed and $0 \%$ strongly disagreed. The third research question, was basically the use of green advertising in protecting firms' reputations. The respondents opined in this manner: strongly agree $36.7 \%$, agree $29.5 \%$, undecided $18.2 \%$, disagree $11.4 \%$ while the percentage of respondents who strongly disagreed that green advertising could protect a company's reputation were $4.5 \%$. Green advertisement added values to our products was the focus of the 
fourth research question and 145 respondents strongly agreed or agreed with the fact which represented $66.2 \%$ of the total respondents, 40 respondents representing $18.2 \%$ were undecided, $15.9 \%$ gave a contrary opinion by not agreeing with the statement.

The focus of the fifth research question from the table above was on green advertisement being a veritable source of information. The responses again were 39 respondents representing $21.1 \%$ strongly agree. Those that agree were $49.7 \%$, undecided $17.3 \%$, disagreed $7 \%$ and $4.9 \%$ strongly disagreed. The sixth question revealed that green advertising was a good way of addressing environmental problems and a high percentage of respondents supported this assertion and the entire result was published on the table above. "Green advertisement by companies is trustworthy" was the focus of the seventh research question. Statistical results revealed the following: strongly agree 90 respondents representing $40.9 \%$ of the total respondents, 74 respondents equally agreed with this statement and it represented $33.6 \%$ of the total respondents, 35 respondents amounting to $15.9 \%$ of the entire respondents disagreed while 20 respondents amounting to $9.1 \%$ of the entire respondents strongly disagreed with the assertion. In research question eight, firms equally believed that green advertisement strengthened a company's image. That was revealed with a large of $75 \%$ that agreed and strongly agreed with the statement.

Finally, green advertisement shows the consumer that our firm is addressing consumers environmental concerns and responses from respondents were as follow: 85 respondents representing $38.6 \%$ of the entire respondents strongly agreed, 67 respondents amounting to $30.5 \%$ agreed, 43 respondents amounting to $19.5 \%$ of the entire respondents were undecided, 23 respondents amounting to $10.5 \%$ disagreed while 2 respondents amounting to $0.9 \%$ of the entire respondents strongly disagreed that green advertisement addressed environmental problems affecting the public. By and large, from the many respondents that agreed or strongly agreed with the statement, one could say without any iota of doubt that green advertisement equally helped in addressing environmental challenges facing society. The aggregate mean of firms' environmental advertisement was 3.8 which also signified that firms' environmental advertisement was effective.

Table 3 - Competitive Advantage of Firms

\begin{tabular}{|c|c|c|c|c|c|c|}
\hline Variables & ๘ & $\varangle$ & د & 口 & œ & $\sum_{\Sigma}^{\frac{\mathbb{\Phi}}{\Sigma}}$ \\
\hline Factors & $\stackrel{\bigodot}{\longleftarrow}$ & $\stackrel{\overbrace{}}{\circ}$ & $\stackrel{\overbrace{}}{\stackrel{0}{\leftrightarrows}}$ & $\stackrel{\overbrace{}}{\stackrel{\circ}{\leftrightarrows}}$ & 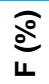 & \\
\hline $\begin{array}{l}\text { Through environmental practices our } \\
\text { company was able to offer } \\
\text { competitive prices to customers. }\end{array}$ & 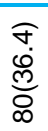 & 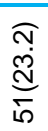 & $\begin{array}{l}\text { กิ } \\
\text { ָู่ } \\
\text { ๐ั }\end{array}$ & 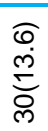 & $\underset{\overparen{I}}{\overparen{+}}$ & $\stackrel{\wp}{\mathscr{\sigma}}$ \\
\hline $\begin{array}{l}\text { Through green marketing practices } \\
\text { my company was able to offer } \\
\text { products that were highly reliable. }\end{array}$ & 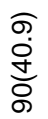 & $\begin{array}{l}\widehat{\sigma} \\
\stackrel{\mathscr{m}}{\mathscr{C}} \\
\stackrel{N}{N}\end{array}$ & 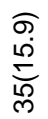 & क্ণ & $\underset{\substack{n \\
0}}{0}$ & $\begin{array}{l}\infty \\
\stackrel{\infty}{m} \\
\dot{m}\end{array}$ \\
\hline $\begin{array}{l}\text { By offering green products, our } \\
\text { company s able to compete offer } \\
\text { better quality to consumers. }\end{array}$ & 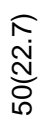 & 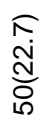 & 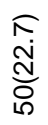 & 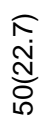 & $\underset{\overparen{D}}{\stackrel{D}{D}}$ & $\stackrel{\substack{\rho \\
m}}{\stackrel{n}{m}}$ \\
\hline $\begin{array}{l}\text { Green marketing practices had } \\
\text { boasted our company's sales. }\end{array}$ & $\frac{\infty}{\infty}$ & 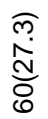 & 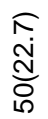 & 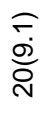 & Б্ণ & Бं \\
\hline $\begin{array}{l}\text { Green marketing practices had } \\
\text { boasted our company's profitability. }\end{array}$ & 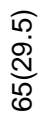 & 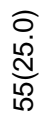 & 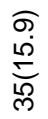 & 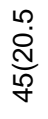 & Б্ণ & $\begin{array}{l}\mathscr{O} \\
\dot{+}\end{array}$ \\
\hline $\begin{array}{l}\text { Green marketing practices had } \\
\text { increased our distributors base. }\end{array}$ & $\begin{array}{l}\overparen{f} \\
\dot{\mathscr{D}} \\
\stackrel{\infty}{\infty}\end{array}$ & 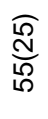 & స: & $\frac{\bar{\infty}}{\stackrel{\infty}{\circ}}$ & $\stackrel{+}{\stackrel{+}{*}}$ & $F_{F}$ \\
\hline
\end{tabular}

Through the practice of green marketing, consumers see our products as dependable brand.

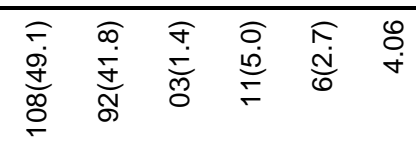

Environmental practices helped us meet our clients' needs better.

As a result of green marketing practices, our company was able to engage in fast product development.

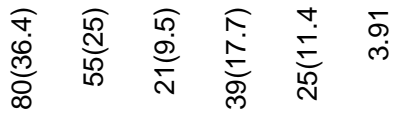

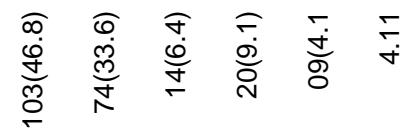

Table 3 dealt on competitive advantage of firms. Nine items were employed to measure the variable. It could be recalled that Elizabeth, Charles and Esther (2015) asserted that the concept of competitive advantage was developed by Porter using several competitive strategies such as (cost leadership, differentiation, and focus) to attain long-range competitive advantage. In the present time, firms still apply Porter's principles to secure an edge over their competitors in the same industry. Through environmental marketing practices, firms are able to offer competitive prices to customers and this was the first item used to measure this variable. The statistical result was as follow: 80 respondents representing $36.4 \%$ of the entire respondents strongly agreed, 51 respondentss amounting to $23.2 \%$ agreed, 50(respondents were undecided, while $17.7 \%$ disagreed or strongly disagreed. By offering green products, firms are able to compete better with competitors in terms of offering better quality and the second research question focused on this. The results obtained from respondents were as follow: $40.9 \%$ strongly agreed with this statement, $33.6 \%$ agreed, $15.9 \%$ were undecided, $9.1 \%$ disagreed while 0.5 strongly disagreed with the assertion. But with the large percentage of respondents supporting this notion, one could say that through environmental practices, firms were able to compete better with competitors in terms of offering better quality that appealed to consumers. The fourth research question focused on the ability of green marketing practices to boast a company's sales. The respondents gave their opinion as follow: strongly agree $31.8 \%$, agree $27.3 \%$, undecided $22.7 \%$, disagreed $9.1 \%$ and strongly disagreed $9.1 \%$. The fifth research question addressed the issue of green marketing practices increasing a company's profitability and the responses received were 65 respondents representing $29.5 \%$ of the total respondents, 55 respondents amounting to $25.0 \%$ agreed, 45 respondents amounting to $20.5 \%$ disagreed, 35 respondents amounting to $15.9 \%$ were undecided, 20 respondents amounting to $9.1 \%$ of the entire respondents strongly disagreed that green marketing practices enhanced a company' profitability.

The sixth research question was on green marketing practices being capable of increasing firms' distributors base. The statistics of respondents were as follow: strongly agree $36.4 \%$, agreed $25 \%$, undecided $9.1 \%$, disagreed $18.1 \%$, strongly disagreed $11.4 \%$. Through the practice of green marketing, consumers see a company's products as a dependable brand was the focus of the seventh research question and responses obtained were as follow: $49.1 \%$ respondents strongly agree with this statement, $41.8 \%$ agreed, $1.4 \%$ were undecided, $5.0 \%$ disagreed while $2.7 \%$ strongly disagreed. Finally, as a result of green marketing practices our company was able to engage in fast product development. The respondents' opinions were as follow: 103 respondents representing $46.8 \%$ of the respondents strongly agreed with this assertion, $33.6 \%$ agreed, $6.4 \%$ were undecided, $9.1 \%$ disagreed and $4.1 \%$ strongly disagreed with this assertion. From the statistical result of the various responses from this segment of competitive advantage, one could say that green marketing practices afforded an organization a competitive edge over other firms in the same industry. The aggregate mean value of firms' competitive advantage was 3.1 signifying that green marketing practices had a good influence on competitive advantage. 


\section{Hypetheses Teseting}

Green marketing practices in our model had two dimensions, that is, ecolabelling and environmental advertisement. The results indicated that the overall model was statistically significant $(\mathrm{F}=$ $82.875, \mathrm{p}<0.05)$ at $5 \%$ level of significance, which signify a linear relationship between green marketing and its explanatory variables.

Table 4 - Relationship between Green Marketing Practices and Competitive Advantage.

\begin{tabular}{|c|c|c|c|c|c|c|}
\hline$N$ & $\boldsymbol{R}$ & $\begin{array}{l}\text { Adjuste } \\
d R\end{array}$ & $\boldsymbol{R}^{2}$ & $\boldsymbol{F}$ & $\begin{array}{l}P \text { - } \\
\text { value }\end{array}$ & $\begin{array}{l}\text { D - } \\
\text { Wat } \\
\text { son }\end{array}$ \\
\hline 220 & $\begin{array}{l}0.6 \\
90\end{array}$ & 0.471 & $\begin{array}{l}0.477 \\
\text { B }\end{array}$ & $\begin{array}{l}82.875 \\
\text { t Stat }\end{array}$ & $\begin{array}{l}0.000 \\
P \text { - } \\
\text { value }\end{array}$ & $\begin{array}{l}2.1 \\
09\end{array}$ \\
\hline \multicolumn{2}{|c|}{ Intercept } & & 9.318 & 3.364 & $.001^{*}$ & \\
\hline \multicolumn{2}{|c|}{$\begin{array}{l}\text { Eco-labelling } \\
\text { Environmental }\end{array}$} & & $\begin{array}{l}-1.39 \\
0.777\end{array}$ & $\begin{array}{l}-.1 .546 \\
12.433\end{array}$ & $\begin{array}{l}.124 \\
.000^{\star}\end{array}$ & \\
\hline
\end{tabular}

* Significant at 0.05

Source: Author's field work, 2018

Green marketing practices in our model had two dimensions, that is, ecolabelling and environmental advertisement. The results indicated that the overall model was statistically significant $(\mathrm{F}=$ $82.875, \mathrm{p}<0.05)$ at $5 \%$ level of significance, which signify a linear relationship between green marketing and its explanatory variables. The R2 value of $47.7 \%$ showed that over 48 percent of the systematic variations in green marketing practices were explained by the regressors in the model. Durbin Watson test was carried out as a key diagnostic test for regression which established if there was presence of autocorrelation in the model's residuals. Given the Durbin Watson value of 2.109 , there was a clear indication that there was no autocorrelation in the model's residuals, making the estimate reliable for policy analysis. Eco-labelling, according to the model, was not significant to competitive advantage as the $\mathrm{p}<0.311$ was greater than 0.005 . Environmental advertisement had a significant relationship with competitive advantage at $\mathrm{p}<0.05$.

\section{HYPOTHESIS ONE}

Eco-labelling has no effect on competitive advantage of table water production in Nigeria. From table 4. eco-labelling was not significantly related to competitive advantage. The impact of ecolabelling on competitive advantage was $(\beta=-1.39, \mathrm{p}=0.124)$. Hence, we retained the null hypothesis which stated that eco-labelling had no effect on competitive advantage in the of table water production in Nigeria as the $\mathrm{p}$ - value was more than $5 \%$ level of significance. We therefore concluded that eco-labelling had no effect on competitive advantage of table water production in Nigeria. according to this study.

\section{HYPOTHESIS TWO}

Environmental advertisement has no effect on competitive advantage of table water production in Nigeria. From table 4 environmental advertisement was significantly and positively related to competitive advantage. The impact of environmental advertisement on competitive advantage was $(\beta=0.777, p=0.000)$. Hence, we rejected the null hypothesis which stated that environmental advertisement had no effect on competitive advantage of table water production in Nigeria. as the $\mathrm{p}-$ value is less than $5 \%$ level of significance. We therefore, concluded that environmental advertisement had influence on competitive advantage of table water production in Nigeria.

\section{Discussion of Findings}

The findings of this study reveal that eco-labelling influence on competitive advantage was not significant in this study. This contradicted the findings of Kristina (2017) who saw eco-labelling as a veritable tool for firms to obtain competitive advantage. Also, this paper revealed a positive significant relationship between environmental advertisement and competitive advantage. Which implies that when a company embarked on good environmental advertisement devoid of greenwash, such a firm could obtain competitive advantage if the environmental advertisement was not deceptive. The findings supported Komal (2015) who found a positive relationship between green/environmental advertising and consumer purchase intention. It further implied that the adoption of green advertising by a business firm attracted more customers thereby giving the firm a competitive advantage over other firms. There exist a positive and significant relationship of environmental advertising to competitive advantage was in line with the apriori expectation of this study.

\section{Conclusion}

Green marketing is regarded as a modern strategy employed by businesses because it helps to strengthen the relationship that existed between the organisations and the community on one side, and also the relationship that exist between organisations and environmental protection agencies on the other hand (Abdullah \& Abdelmo'ti, 2015). Table water companies in Nigeria. should be able to explore the potential of green marketing as a tool for competing in today's markets where consumers are conscious of health and environmental implications of the types of products they purchase.

On the basis of this, the study investigated the effect of green marketing on competitive advantage of table water production in Nigeria. Despite the relevance of green marketing, most organisations' products are not environmentally friendly as their production and marketing efforts are yet to conform to the standard prescribed by the regulatory agencies. Most organisations are oblivious of the fact that producing environmentally friendly products would project their corporate image in the eyes of the consumers and hence give them an edge over other firms that do not practise green marketing. It is worth noting that the need for the practice of green marketing prompts the demand for the consumption of green products (Chen, 2010; Ali \& Ahmad, 2012). It is also worth mentioning that through the implementation of green marketing strategies, firms can create more needs and reach out to new markets that were hitherto not available (Gunderson, 2014).

\section{Recommendations}

This study therefore makes the following recommendations:

i. that table water factories should carryout eco-certification of their products from certification agencies. This will further prove to consumers that their products are environmentally friendly.

ii. table water factories should ensure proper green advertisement devoid of greenwash. In otherwords, their green advertisement should be reflective in the product they are advertisement.

iii. table water companies should know that in spite of the huge capital outlay on table water equipment and other facilities, more important is the greenness of their products which will make consumers to prefer them to other table water companies and this could lead to competitive advantage.... Multiple regression analysis was used to analyse the impact of various factors leading towards student loyalty in higher education

\section{References:}

Abdullah, M. A., \& Abdelmo'ti, S.A. (2015). The impact of application green marketing criteria on the marketing performance. Global Journal of Management and Business Research, 1(5), 36-37. Retrieved on the 4th of August, 2017.

Ajike, E. O., Amos, N. B., \& Kabuoh, M. N. (2015). Green marketing: A tool for achieving sustainable development in Nigeria. International 
Journal of Advanced Research in Statistics, Management and Finance, $3(1), 1-14$.

Ajzen, I. (1991). The theory of planned behavior. Organizational Behavior and Human Decision Processes, 50(2), 179-211.

Ali, A., \& Ahmad, I. (2012). Environmental friendly products: Factors influence the green purchase intention of Pakistan consumers. Pakistan Journal of Engineering Technology Science, 2(1), 84-117.

Chang, N. J., Fong, C. M. (2010). Green product quality, green corporate image, green customer satisfaction and green loyalty. African journal of business management, 4(13), 2836-2844.

Chen, Y.S. (2010). The drivers of green brand equity: Green brand image, green satisfaction, and green trust. Journal of Business Ethics, 93(1), 81-92.

Delafrooz, N., Taleghani, M., \& Nouri, B. (2014). Effect of green marketing on consumer purchase behavior. QScience Connect. doi.org/10.5339/connect.2014.5.

Elizabeth, M. O., Charlse, M., \& Esther, T. A. (2015). Sustainabilitycompetitive advantage? Proceedings of the International Conference on Operations Excellence and Service Engineering Orlando, Florida, USA.

ISO (1999). Environmental labels and declarations - type I environmental labelling - principles and procedures. Geneva, Switzerland.

Iweama, V. (2008) Attitudes of Nigerian consumers and the firms green marketing strategy towards the environment. M.Sc Research Project Presented to the Marketing Department, Nnamdi Azikiwe University Awka.

Karatu, V. M. H. \& Nik K, N. (2015). Predictors of green purchase intention in Nigeria: The mediating role of environmental consciousness. American Journal of Economics. 5(2), 291-302.

Kinoti, M. W. (2011). Green marketing intervention strategies and sustainable development: a conceptual paper. International journal of business and social science, 2(23), 263-273.

Komal, N. (2015). Modeling the effects of green advertising on brand image: Investigating the moderating effects of product involvement using structural equation. Journal of global marketing, 28 (3/5), $152-171$. https://doi.org/10.1080/08911762.2015.1114692

Kumar, V., Rahman, Z., Kazmi, A. A., \& Goyal, P. (2013). Evolution of sustainability as marketing strategy: Beginning of New Era. Social and Behavioral Sciences, 482-489.

Low, S. P., Gao, S., \& See, Y. L. (2014). Strategies and measures for implementing eco-labelling schemes in Singapore's construction industry. Resources, Conservation and Recycling, 89, 31-40.

Mishra, P., \& Sharma, P. (2008). Green marketing: challenges and opportunities for business. Journal of marketing and communication, $8(1), 35-41$.

Mukesh, S., Komal, M. \& Rajendra, K. (2016). Consumers' Readiness for Green Products and its effect on sustainable development. Amity Journal of Marketing, 1(1), 93-104

Narges, D., Mohammad, T., \&, Bahareh, N. (2014). Effect of green marketing on consumer purchase behavior. A Qatar Academic Journal. Retrieved from http://dx.doi.org/ 10.5339/connect.

Nkamnebe, A.D. (2009). Globalized Marketing and the Question of Development in the Sub Saharan Africa (SSA). Critical Perspectives on International Business 2(4).

Nkamnebe, A.D. (2011). Sustainability marketing in the emerging markets: Imperatives, challenges and agenda setting. International Journal of the Emerging Market, 6(3), 217 - 232.

Porter, M., (1995). Competitive advantage: Creating and sustaining superior performance. New York: Free Press.

Rahbar, E., \& Abdul, W. N. (2010). Consumers' perception of green products category: Implication of SMEs. Penang: SME and Marketing Mini Conference. .Retrieved from scholar.google.com.

Rijamampianina, R., Abratt, R., \& February, Y. (2003). A framework for concentric diversification through sustainable competitive advantage, Management Decision, 41(4), 362-371.

Shahriar, R., Mahbubul, H. (2016). Eco-branding: A way to sustainable business opportunities in Bangladesh. European Journal of Business and Management, .8 (9), $14-15$.

Singh, G. (2013). Green: The new colour of marketing in India. ASCI Journal of Management, 42(2), 52-72.

Srinivasa, R. V. (2014). Green marketing and its impact on sustainable development. International Journal of Innovative Technology \& Adaptive Management, 1(5), 23-45.

Stern, P. ((2000). Toward a coherent theory of environmentally significant behavior. Journal of Social Issues, 56 (3), 7-24.

Thulasimani, P. (2012). Green Products and Green Marketing. International Journal of Research in Finance and Marketing,3, 448-453.

Yamane, Taro. (1967). Statistics: An Introductory Analysis, 2nd Edition, New York: Harper and Row.
National Agency Food Drug Administration and Control (2016). Annual Report, Abuja: NAFDAC Office.

www.dayoadetiloye.com/4 major challenges of pure water and table water business are facing in Nigeria. Retrieved on the 12th of April, 2019. 